\title{
The effect of diet and aerobic exercise on Premenstrual Syndrome: Randomized controlled trial
}

\author{
O efeito da dieta e do exercício aeróbio na \\ Sindrome Pré-menstrual: ensaio \\ controlado de modo aleatório
}

Elvan YILMAZ-AKYUZ1 ID 0000-0002-1878-9412
Yasemin AYDIN-KARTAL² ID 0000-0001-7464-945X

A B S T R A C T

\section{Objective}

This study was conducted to determine the effectiveness of aerobic exercise and diet in female students with Premenstrual Syndrome Scale who were studying at the public university.

\section{Methods}

This randomized controlled trial was conducted in a public university in 2018. The population of the study was composed of all female first graders ( $\mathrm{N}=426)$. The female students were followed-up for two cycles, premenstrual syndrome scale was administered to the students and premenstrual syndrome was found in $43.8 \%(n=187)$. However, 106 female students were included in the study divided in three groups (diet, aerobic exercise, control). The diet and aerobic exercise were administered during the three months.

\section{Results}

There was no significant difference in premenstrual syndrome scale mean scores between the post-intervention groups. However, the mean premenstrual syndrome score of the diet and aerobic exercise groups decreased significantly after the intervention. There was a significant difference in visual analogue scale score between the groups after intervention. Besides the students in exercise and diet groups experienced less dysmenorrhea intensity than the control group.

\section{Conclusion}

It was found that diet and aerobic exercise were effective in reducing the symptoms of premenstrual syndrome and dysmenorrhea intensity in female students with premenstrual syndrome.

Keywords: Aerobic exercise. Diet. Pain. Premenstrual Syndrome.

1 University of Health Sciences, Faculty of Health Sciences, Department of Nutrition and Dietetics. Selimiye District, Trbbiye Street, 34668, Istanbul, Turkey. Correspondence to: E YILMAZ-AKYUZ. E-mail: <elvan.yilmazakyuz@sbu.edu.tr>.

2 University of Health Sciences, Faculty of Health Sciences, Department of Midwifery. Istanbul, Turkey.

How to cite this article

Yilmaz-Akyuz E, Aydin-Kartal A. The effect of diet and aerobic exercise on Premenstrual Syndrome: Randomized controlled trial. Rev Nutr. 2019;32:e180246. http://dx.doi.org/10.1590/1678-9865201932e180246 


\section{R E S U M O}

\section{Objetivo}

Este estudo foi feito para determinar a efetividade do exercício aeróbico e dietéticos em alunos mulheres com Sindrome Pré-Menstrual que estudaram na universidade pública.

\section{Métodos}

Este estudo foi conduzido como um ensaio clínico randomizado controlado na universidade pública EM 2018. A população do estudo foi composta por todas as mulheres de primeiro ano $(N=426)$. As mulheres foram monitoradas durante dois ciclos. A Escala de Síndrome Pré-Menstrual foi administrada nas alunas e, em 43,8\%, foi encontrada a Síndrome Pré-Menstrual ( $n=187)$. O estudo incluiu 106 mulheres. O estudo foi realizado de forma aleatória e em três grupos (dieta, exercício aeróbico, controle). Dieta e exercícios aeróbicos foram administrados por três meses.

\section{Resultados}

Na intervenção subsequente não houve diferenças significativas nos escores médios da escala Síndrome Pré-Menstrual entre os grupos. No entanto, o escore médio do Síndrome Pré-Menstrual nos grupos de exercícios aeróbicos e dieta diminuiu significativamente após a intervenção. Houve diferença significativa no escore médio da escala visual analógica entre os grupos após a intervenção. Foi determinado que os estudantes dos grupos de exercício e dieta experimentaram menos intensidade de dismenorreia que o grupo do controle.

\section{Conclusão}

Determinou-se que a dieta e o exercício aeróbico eram eficazes em reduzir os sintomas da síndrome pré-menstrual e a intensidade da dismenorreia em estudantes com síndrome pré-menstrual.

Palavras-chave: Exercício aeróbico. Dieta. Dor. Síndrome Pré-Menstrual.

\section{NTRO D U C T I O N}

Premenstrual Syndrome (PMS) is a disorder that is frequently seen in young adult women, affecting daily life, and showing dominant emotion fluctuations, especially in the late luteal phase of menstruation. It usually ends in a few days after menstruation begins [1]. PMS affects women's mental and physical health and its prevalence is approximately $48 \%$ in women of reproductive age [2]. The common psychological symptoms of PMS are reported as anger, anxiety, depression, mood fluctuations, poor concentration, nervousness, despair and physical symptoms like swelling and edema in breast, abdominal bloating, muscle and joint pain, headache, fatigue, over-eating and weight gain $[3,4]$.

Genetic factors, hormones, diet and lifestyle are reported to be the related factor for PMS [5-7]. However, its underlying mechanism is not clear. There are several treatment recommendations for the management of PMS symptoms, but there is no definitive treatment. Recently, lifestyle change has gained more importance than pharmacotherapy. Lifestyle changes include many methods including diet regulation and exercise. In the studies, 30 minutes of aerobic exercise is recommended for at least 3 days per week to contribute to the regulation of both body composition, mood and to improve physical symptoms $[8,9]$. Also some studies recommend for 60 minutes of aerobic exercise $[10,11]$. In addition, balanced diet, reduction of salt, caffeine and refined sugar intake, restricted high and saturated fat, increasing the consumption of omega-3, magnesium, zinc, vitamins B and $E$ are effective in reducing PMS symptoms [1,6,12-15].

Premenstrual Syndrome has a negative impact on young girls' lives, which can lead to reduced work efficiency and quality of work, increased accidents and lack of school attendance. Therefore, there is a need to develop treatment protocols for coping with premenstrual symptoms. This study 
was conducted in order to investigate the effect of diet regulation and aerobic exercise on female students with Premenstrual Syndrome complaints.

\section{METHOD S}

This randomized controlled trial was conducted in 2018 at the Faculty of Health Sciences of a public university according to the declaration of Helsinki with the approval of Ethics Committee of the University of Health Sciences (Decision No.18/06-050.03.04).

The population of the study consisted of all first-year female students studying at the faculty $(\mathrm{N}=426)$. All students were followed up for two cycles in order to determine the presence of PMS. Premenstrual Syndrome Scale was applied to the participants and the prevalence was found as $43.8 \%$ $(n=187)$. In order to determine the number of samples, power analysis was performed by using $G$ * Power (v3.1.7) software (Informer Technologies Inc., Dusseldorf, Germany). Taking into account the data obtained from the research on the same subject, power was calculated as $0.8, a=0.05$ and $\beta=0.19$ [16]. According to this, it was calculated that there should be at least 35 people in the groups (Figure 1).

Students included in the study were randomly divided into three groups by closed envelope method. The groups were chosen by students by random withdrawal of envelopes including the names of groups prepared by researcher. While withdrawal, the researcher also did not know which envelope was including which group.

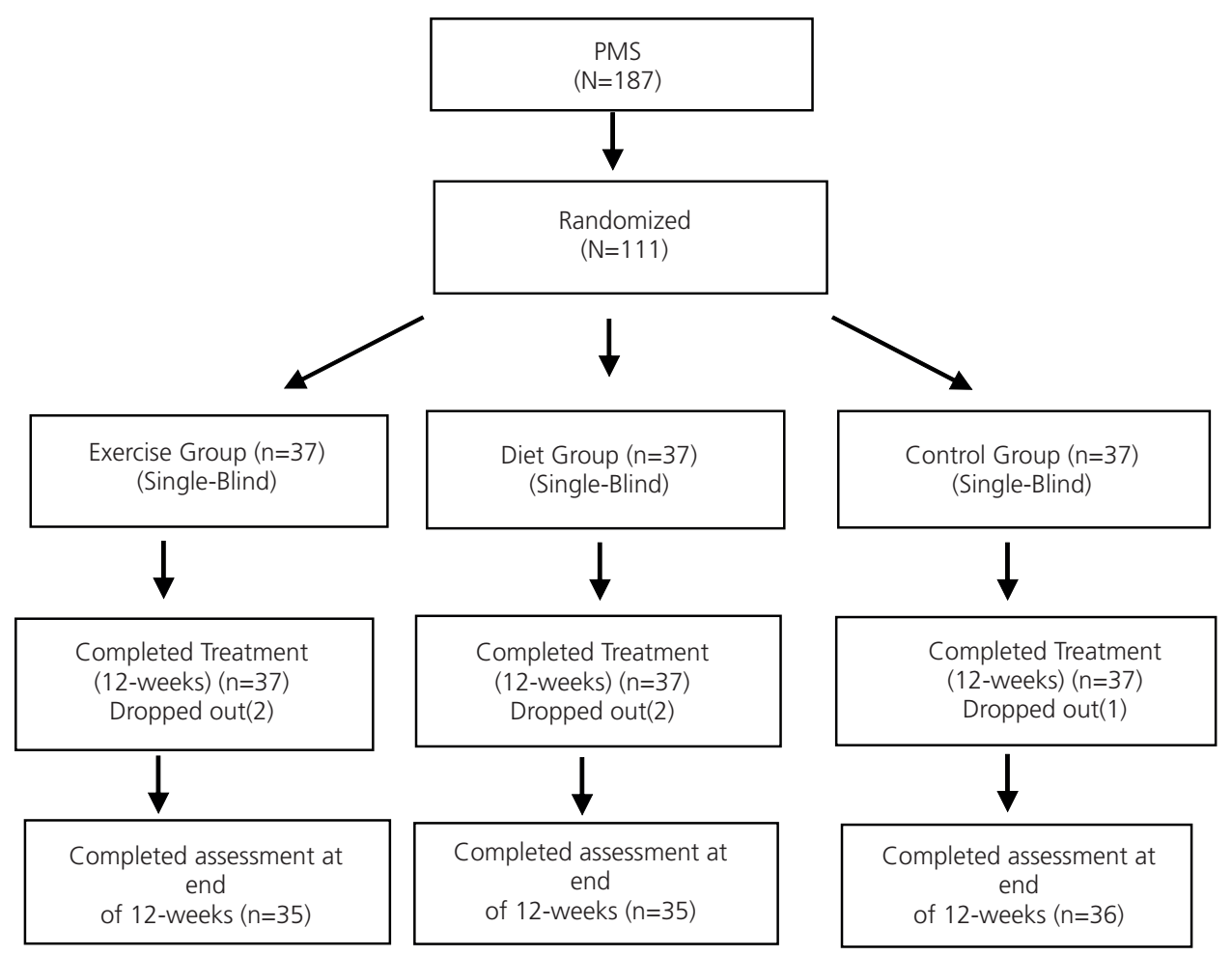

Figure 1. Flow-chart of the study. 
Female students aged between 18-35 years, having Body Mass Index (BMI) 18,5-29,9kg/m² and regular menstrual cycles were included in the study. Exclusion criteria of the study were presence of diabetes, mental and physical illness, diagnosed psychological disorder, liver and kidney dysfunction, endocrine drug use, history of joint, movement and muscle diseases, endometriosis, pregnancy or lactation period, smoking and alcohol use, thyroid and heart disease, polycystic ovary syndrome, oral contraceptive and antidepressant use, previously received training related to nutrition, PMS and physical activity, regular exercise, being a licensed athlete, the use of vitamin-mineral or herbal supplement.

Student Information Form, Visual Analogue Scale (VAS), Premenstrual Syndrome Scale (PMSS) and Food Frequency Questionnaire (FFQ) were applied to the all students before the intervention. Diet and aerobic exercise were applied to the participants for three menstrual cycles (avarage 12-weeks). After completion of three menstrual cycles, VAS and PMSS were repeated to all groups.

Data Collection Instruments: The study data were collected by using "Student Information Form", including demographic information of the participants, which was developed by the researchers, PMSS to determine the frequency of PMS, VAS to score pain severity and FFQ to determine nutritional status.

Student Information Form: This form includes questions about the personal characteristics of the students, descriptive information about the menstruation period, anthropometric measurement, frequency of some foods intake, and physical activity levels.

Premenstrual Syndrome Scale (PMSS): The scale is developed by Gençdogan [17] to measure premenstrual syndrome with 44 items and it is likert type. The scale is valiable and reliable in PMS. The presence of PMS is evaluated according to the fact that it exceeds $50 \%$ of the highest score can be taken from total scale and subscales. Increased score means that the symptoms of premenstrual syndrome are high. The Cronhach's Alpha coefficient of the scale was found to be 0,816 before application and 0,864 after the application.

Visual Analogue Scale (VAS): In order to determine the severity of dysmenorrhea, patients were asked to mark a suitable point on a horizontal line with a length of $10 \mathrm{~cm}$. The point marked on the line was measured and recorded. In terms of the impact of the current situation on life, 0 indicates no pain, 10 indicates excruciating pain. Pain scale measurement is classified as mild pain 1-4, moderate pain 5-6 and severe pain 7-10. VAS is a valid scale for assessing pain, dysmenorrhea severity and PMS symptoms $[18,19]$.

Food Frequency Questionnaire (FFQ): The questionnaire was prepared according to literature by research dietitian $[1,4,12,20,21]$. It contains 10 questions asking the frequency of consumption of meat, fish, milk and dairy products, legumes, vegetables, fruits, refined carbohydrate-rich foods, sugar, caffeine and carbonated beverages, chocolate and chocolate foods, foods rich in fat and sugar.

\section{Treatment Applications}

Aerobic Exercise: The aerobic exercise program was given to the students individually for 12 weeks, 3 days a week and 30 minutes at the sports center with an experienced trainer. Students were advised to drink water and use running shoes during the exercise. Warm-up exercises were performed for 8 to 10 minutes before exercise. Exercise severity was determined by Karvonen formula $(\mathrm{HRmax}=220-$ Age, HRR=HRmax-HR rest, 60\% THR=(0.60xHRR)+HR rest) [22]. In accordance with the pulse rate of the exercise, the pulse values are followed on the treadmill and the $\mathrm{km} /$ hour speeds are 
adjusted according to the pulse values. The exercise program, which started with low aerobic exercise intensity on the treadmill, was gradually increased in 5-minute intervals and completed at $40-60 \%$ of heart beat and at the final $5 \mathrm{~min}$, light stretching was done to go back to the original state.

PMS Diet: The dietary habits of the students were evaluated, and their diets were organized by an expert dietitian. They were given PMS diet and applied for 12 weeks. PMS diet contains $50-55 \%$ carbohydrate, $25-30 \%$ fat and $15-20 \%$ protein. Diet, rich in complex carbohydrates, refined sugar was limited. Individuals were given 1-2 times a week of fish, daily $>1000 \mathrm{mg}$ of calcium and 20 grams of dried nuts per day and $<300 \mathrm{mg}$ of caffeine consumption. The consumption of, acidic, carbonated foods and the addition of extra salt to the food, was limited $[1,13,15,21]$. The participants kept daily food intake records. The diet treatment of them was followed by telephone or face to face interviews one a week by research dietitian.

Analysis of Data: The data were evaluated with SPSS 25.0 (Statistical Package for Social Sciences, Chicago, Illinois, United States of America) software. In addition to descriptive statistical methods (Mean, Standard Deviation [SD]), ANOVA test, Wilcoxon Signed Ranks Test and Kruskal Wallis test were used to evaluate the data. The significance of the results was evaluated at $p<0.05$ level.

\section{R E S U L T S}

When the socio-demographic characteristics of the students were examined, it was determined that the average age of the students was $19.36 \pm 1.61$ year, the first menarche age was $13.17 \pm 1.32$ year and the mean BMI was $21.26 \pm 2.77 \mathrm{~kg} / \mathrm{m}^{2}$. There was no significant difference between the average age, BMI, age of menarche and menstrual cycle times in the aerobic, diet and control groups before the intervention (Table 1).

Table 1. Demographic characteristics of students. Istanbul, Turkey, 2018.

\begin{tabular}{|c|c|c|c|c|c|c|c|c|c|c|}
\hline \multirow[t]{2}{*}{ Students characteristics } & \multicolumn{3}{|c|}{$\begin{array}{c}\text { Aerobic Group } \\
(n=35)\end{array}$} & \multicolumn{3}{|c|}{$\begin{array}{l}\text { Diet Group } \\
\quad(n=32)\end{array}$} & \multicolumn{3}{|c|}{$\begin{array}{c}\text { Control Group } \\
(n=32)\end{array}$} & \multirow[t]{2}{*}{ Test $^{*}$} \\
\hline & Mean & \pm & SD & Mean & \pm & SD & Mean & \pm & SD & \\
\hline Age (year) & 19.28 & \pm & 1.63 & 19.20 & \pm & 0.83 & 19.61 & \pm & 2.11 & $\mathrm{~F}=0.531, p=0.636$ \\
\hline $\mathrm{BMI}\left(\mathrm{kg} / \mathrm{m}^{2}\right)$ & 21.12 & \pm & 2.80 & 21.05 & \pm & 2.64 & 21.59 & \pm & 2.90 & $\mathrm{~F}=0.400, p=0.671$ \\
\hline Age of menarche & 13.22 & \pm & 1.39 & 12.88 & \pm & 1.13 & 13.41 & \pm & 1.42 & $\mathrm{~F}=1.464, p=0.236$ \\
\hline Duration of menstrual cycle (day) & 6.41 & \pm & 1.48 & 7.01 & \pm & 2.15 & 6.32 & \pm & 2.06 & $\mathrm{~F}=1.122, p=0.066$ \\
\hline
\end{tabular}

Nota: *Anova Test; BMI: Body Mass Index; SD: Standard Deviation.

Menstrual cycle of $87.7 \%$ of the students was between 21-35 days and the menstrual period of $92.5 \%$ of the students was ranging from $2-7$ days. It was determined that $61.3 \%$ of the students complained of primary dysmenorrhea and $48.1 \%$ of the complaints started $2-3$ days before the menstruation and ended 24 hours after the menstruation started. In addition, 56.8\% of the students participating in the study had first-degree relatives with PMS complaints.

As a result of the examination of the premenstrual symptoms that students complained, it was determined that $73.6 \%$ had lower back pain, $61.3 \%$ had pelvic pain, 55.7\% had weakness and fatigue, $52.5 \%$ had irritability, $49.7 \%$ had bloating, $43.4 \%$ had appetite changes, $39.6 \%$ had breast 
tenderness, 34.9\% had depressive thoughts, 29.2\% had frequent urination, $27.4 \%$ had cramp in legs, $18.9 \%$ had headache, $15.1 \%$ had impaired concentration and $14.2 \%$ had sleep disorders.

The coping methods used by the students were mostly resting (78.3\%), using hot application $(60.4 \%)$, analgesics (50.9\%), herbal methods (29.2\%), massage $(21.7 \%)$ and doing physical exercise $(19.6 \%)$. Also, the students were consuming green tea $(17.0 \%)$, chamomile tea $(7.5 \%)$ and sage $(4.7 \%)$ among the herbal methods.

Food consumption frequency of the students before the intervention is shown in Table 2 . In addition, walking (11.3\%), cycling (2.5\%), volleyball (1.9\%), basketball $(0.9 \%)$ and swimming $(1.3 \%)$ were determined as irregular sports activities in participants.

The PMS score of the students indicates that there was no difference between the groups before and after the intervention. However, it was determined that the mean PMS score of the diet and aerobic exercise groups decreased significantly (Table 3).

There was no statistically significant difference between the groups in terms of severity of primary dysfunction before the intervention $(p>0.05)$. After the intervention, the VAS score was significantly lower in the groups that were administered diet and aerobic exercise. In the comparison

Table 2. Food consumption frequency of the students before the intervention. Istanbul, Turkey, 2018.

\begin{tabular}{|c|c|c|c|c|c|c|}
\hline \multirow[t]{2}{*}{ Foods } & $\begin{array}{l}\text { More than } 1 \\
\text { times a day }\end{array}$ & Daily & $\begin{array}{c}\text { 1-2 times a } \\
\text { week }\end{array}$ & $\begin{array}{l}2 \text { times a } \\
\text { month }\end{array}$ & $\begin{array}{l}1 \text { times a } \\
\text { month }\end{array}$ & None \\
\hline & \multicolumn{6}{|c|}{$(\%)$} \\
\hline Milk and Dairy products & 5.7 & 31.1 & 24.5 & 19.8 & 7.6 & 11.3 \\
\hline Meat & 4.7 & 43.4 & 25.5 & 13.2 & 9.4 & 3.8 \\
\hline Legumes & 0.0 & 23.6 & 38.7 & 23.6 & 10.3 & 3.8 \\
\hline Fish & 0.0 & 0.0 & 10.4 & 10.4 & 36.7 & 42.5 \\
\hline Vegetables & 8.5 & 11.3 & 25.5 & 39.6 & 12.3 & 2.8 \\
\hline Fruits & 1.9 & 16.9 & 21.7 & 25.5 & 23.6 & 10.4 \\
\hline Refined Carbohydrate-rich Foods & 33.0 & 50.1 & 9.4 & 4.7 & 2.8 & 0.0 \\
\hline Sugar, Caffeine and Carbonated Beverages & 37.7 & 35.8 & 18.9 & 7.6 & 0.0 & 0.0 \\
\hline Chocolate and foods including chocolate & 9.5 & 58.4 & 28.3 & 2.9 & 0.0 & 0.9 \\
\hline Fat-rich and Sugar-rich Foods & 7.6 & 57.5 & 18.9 & 9.4 & 6.6 & 0.0 \\
\hline
\end{tabular}

Table 3. Comparing the mean scores of Premenstrual Syndrome Scale in the tree groups. Istanbul, Turkey, 2018.

\begin{tabular}{|c|c|c|c|c|c|c|c|c|c|c|c|}
\hline \multirow[t]{2}{*}{ Scale } & & \multicolumn{3}{|c|}{$\begin{array}{l}\text { Diet Group } \\
\quad(n=32)\end{array}$} & \multicolumn{3}{|c|}{$\begin{array}{l}\text { Aerobic Group } \\
\quad(n=32)\end{array}$} & \multicolumn{3}{|c|}{$\begin{array}{c}\text { Control Group } \\
(n=35)\end{array}$} & \multirow[t]{2}{*}{ Test $^{*}$} \\
\hline & & Mean & \pm & SD & Mean & \pm & SD & Mean & \pm & SD & \\
\hline \multirow{3}{*}{$\begin{array}{l}\text { PMS } \\
\text { Total score }\end{array}$} & First $\mathrm{E}$. & 120.62 & \pm & 33.03 & 131.69 & \pm & 34.53 & 113.47 & \pm & 33.09 & $\begin{array}{l}{ }^{*} z=5.943 \\
p=0.051\end{array}$ \\
\hline & Last $\mathrm{E}$. & 112.20 & \pm & 29.47 & 117.51 & \pm & 31.98 & 112.36 & \pm & 32.50 & $\begin{array}{l}{ }^{*} z=1.056 \\
p=0.590\end{array}$ \\
\hline & $z / p$ & ${ }^{* *} \mathrm{z}=-4.3$ & & $=0.000$ & ${ }^{* *} z=-4$ & 111 & $=0.000$ & ${ }^{* *} \mathrm{z}=-$ & 97 & $=0.058$ & \\
\hline
\end{tabular}

Note: "Kruskal Wallis Test; ${ }^{* *}$ Wilcoxon Signed Ranks; First E: First Evaluation; Last E: Last Evaluation; PMS: Premenstrual Syndrome; SD: Standard Deviation. 
between the groups, there was no significant difference between the VAS score in the diet and aerobic exercise group, but it was significantly decreased in both groups compared to the control group (Table 4).

Table 4. Comparing the mean scores of primary dysmenorrhea in the tree groups. Istanbul, Turkey, 2018.

\begin{tabular}{|c|c|c|c|c|c|c|c|c|c|c|c|}
\hline \multirow[t]{2}{*}{ Scale } & & \multicolumn{3}{|c|}{$\begin{array}{c}\text { Diet Group } \\
(n=32)\end{array}$} & \multicolumn{3}{|c|}{$\begin{array}{l}\text { Aerobic Group } \\
\quad(n=32)\end{array}$} & \multicolumn{3}{|c|}{$\begin{array}{l}\text { Control Group } \\
\quad(n=35)\end{array}$} & \multirow[t]{2}{*}{ Test $^{*}$} \\
\hline & & Mean & \pm & SD & Mean & \pm & SD & Mean & \pm & SD & \\
\hline \multirow{3}{*}{$\begin{array}{l}\text { VAS } \\
\text { Total score }\end{array}$} & First $\mathrm{E}$. & 7.07 & \pm & 1.32 & 7.40 & \pm & 1.31 & 6.91 & \pm & 1.13 & $\begin{array}{l}{ }^{*} \mathrm{z}=1.876 \\
p=0.391\end{array}$ \\
\hline & Last $\mathrm{E}$. & 4.91 & \pm & 1.64 & 4.31 & \pm & 1.25 & 6.69 & \pm & 1.21 & $\begin{array}{r}{ }^{*} \mathrm{z}=23.862 \\
p=0.000\end{array}$ \\
\hline & $z / p$ & \multicolumn{3}{|c|}{${ }^{* *} \mathrm{z}=-6.369 / p=0.000$} & \multicolumn{3}{|c|}{${ }^{* *} z=-5.120 / p=0.000$} & \multicolumn{3}{|c|}{${ }^{* *} z=-1.597 / p=0.110$} & \\
\hline
\end{tabular}

Note: "Kruskal Wallis Test; ${ }^{* *}$ Wilcoxon Signed Ranks; First E: First evaluation; Last E: Last evaluation; SD: Standard Deviation; VAS: Visual Analogue Scale.

\section{DISCUSSION}

PMS is common in women of reproductive age. However, the effects of diet and aerobic exercise intervention in university students with PMS have not been investigated comparatively previously. Therefore, the study was carried out to alleviate the effects of PMS and to develop alternative treatment protocols. In this study, PMS was found in $43.80 \%$ of the students. PMS prevalence studies conducted among university students in Turkey are reported to be between $36.00 \%$ and $92.00 \%$ $[23,24]$. In different countries, the frequency has been reported to vary from $39.85 \%$ to $98.20 \%$ $[4,6,25]$. The fact that international prevalence is variable is due to the ethnic and cultural differences as well as the methods used to describe the PMS. However, other studies and our study agree that a high rate is seen in university students.

It is known that genetic transmission is a risk factor for PMS. We found that $56.8 \%$ of female students with PMS had first degree relatives such as mothers or sisters with PMS. The results of our study support the fact that the family history is a risk factor for PMS.

The most commonly reported PMS symptoms in our study were $73.6 \%$ lower back pain, $61.3 \%$ pelvic pain, $55.7 \%$ weakness and fatigue, $52.5 \%$ irritability, $49.7 \%$ bloating, $43.4 \%$ appetite changes, 39.6\% breast tenderness and swelling and 34.9\% depressive thoughts. All these complaints cause a decrease in the quality of life, productivity and school performance of young women $[6,23]$. Therefore, it is important to determine common premenstrual symptoms and to make planning for effective treatment.

There are many studies that show that there is a relationship between PMS and nutrition $[1,13,15,21]$. Johnson et al. [12] reported in their study that high-energy nutrition from carbohydrate is negative on PMS. Reed et al. [7] found that women with PMS consumed higher fat and carbohydrates. Similarly, consumption of high starchy foods was inversely related to PMS complaints, high sugar content, and consumption of caffeinated foods and beverages were reported to be associated with PMS [1]. In a study comparing healthy, traditional and western diet, it was found that western diet was more related to PMS than others [26]. Dietary modifications are recommended for the treatment of PMS, but the number of studies is limited, except the effects of micronutrient supplements studies on 
symptoms. Recently, Esmaeilpour et al. [27] determined that daily intake of whole grains had positive effect on mood, physical and behavioral symptoms of PMS. We found that university students with PMS consumed high amounts of fatty, sugary, chocolate and refined carbohydrates, but they were limited to vitamins, minerals and fiber rich in vegetables, fruits and legumes. This suggests that PMS requires a personalized diet protocol to reduce PMS symptoms. In the study, it was determined that PMS symptoms decreased significantly with PMS diet.

Studies have reported that regular aerobic exercise reduces PMS severity.In particular, it is stated that exercise is effective in anxiety and other neurovegetative symptoms, and this increases the level of brain endorphins and decreases adrenal cortisol [28]. Morino et al. [29] reported in their study that daily excessive physical activity as well as inactivity was associated with symptoms. They found that PMS rates were lower in those who had normal physical activity dail. In some studies were reported that regularly, moderate aerobic exercise reduced PMS symptoms and could be used as a treatment method $[8,10,11]$. Baat et al. [9] also determined to regular aerobic exercise positive effect on PMS. The findings of the study support the literature and it was determined that three months of aerobic exercise decreased the PMS complaints significantly. This suggests that a physically active lifestyle can be effective in treating PMS.

Limitations: this study was conducted at one public university. The questionnaire was used as data collection tool and the data were processed according to the participants' statements. The follow-up process was only three months.

\section{CONCLUSION}

As a result, it was determined that most of the female students at the university had PMS complaints. Diet and aerobic exercise were effective in decreasing dysmenorrhea density with PMS symptoms. However, the two interventions have no superiority over each other. In order to provide healthy living habits to university students, appropriate conditions can be provided in the school environments where they spend most of their time and trainings on the effects of diet and aerobic exercise on PMS can be given. In addition, medical support treatment can be provided with a multidisciplinary team for the relief or alleviation of symptoms.

\section{CONTRIBUTORS}

E YILMAZ-AKYUZ was responsable for the conception and design of the study, data collection, literature search, writing and editing of manuscript. Y AYDIN-KARTAL collaborated with data collection, statistical analysis, manuscript writing, approval of the final version. All authors contributed to and have approved the final version.

ACKNOWLEDGMENTS

The authors thank the participants for their support with the data collection.

\section{REFERENCES}

1. Nagata C, Hirokawa K, Shimizu N, Shimizu H. Soy, fat and other dietary factors in relation to premenstrual symptoms in Japanese women. BJOG. 2004;111(6):594-9. http://dx.doi.org/10.1111/j.1471-0528.2004. 00130.x 
2. Direkvand-Moghadam A, Sayehmiri K, Delpisheh A, Kaikhavandi S. Epidemiology of Premenstrual Syndrome (PMS): A systematic review and meta-analysis study. J Clin Diagn Res. 2014;8(2):106-9. http://dx.doi. org/10.7860/JCDR/2014/8024.4021

3. Choi D, Lee DY, Lehert P, Lee IS, Kim SH, Dennerstein L. The impact of premenstrual symptoms on activities of daily life in Korean women. J Psychosom Obstet Gynaecol. 2010;31(1):10-5. http://dx.doi. org/10.3109/01674820903573920

4. Seedhom EA, Mohammed ES, Mahfouz EM. Life style factors associated with premenstrual syndrome among ElMinia University students, Egypt. ISRN Public Health. 2013:617123. http://dx.doi.org/10.1155/2013/617123

5. Matsumoto T, Asakura H, Hayashi T. Biopsychosocial aspects of Premenstrual Syndrome and premenstrual dysphoric disorder. Gynecol Endocrinol. 2013;29(1):67-73. http://dx.doi.org/10.3109/09513590.2012.705383

6. Cheng SH, Shih CC, Yang YK, Chen KT, Chang YH, Yang YC. Factors associated with Premenstrual Syndrome: A survey of new female university students. Kaohsiung J Med Sci. 2013;29(2):100-5. http://dx. doi.org/10.1016/j.kjms.2012.08.017

7. Reed SC, Levin FR, Evans SM. Changes in mood, cognitive performance and appetite in the late luteal and follicular phases of the menstrual cycle in women with and without PMDD (premenstrual dysphoric disorder). Horm Behav. 2008;54(1):185-93. http://dx.doi.org/10.1016/j.yhbeh.2008.02.018

8. Dehnavi ZM, Jafarnejad F, Goghary SS. The effect of 8 weeks aerobic exercise on severity of physical symptoms of premenstrual syndrome: A clinical trial study. BMC Womens Health. 2018;18:80-7. http:// dx.doi.org/10.1186/s12905-018-0565-5

9. Baat A, Yagin S, Dei M. Effect of exercise on Premenstrual Syndrome. Inter J Med Public Health. 2018;2(1):11-6.

10. Samadi Z, Taghian F, Valiani M. The effects of 8 weeks of regular aerobic exercise on the symptoms of Premenstrual Syndrome in non-athlete girls. Iran J Nurs Midwifery Rs. 2013;18(1):14-9.

11. Cicek $G$. The effect of regular aerobic exercises on Premenstrual Syndrome in sedentary women. Balt J Health Phys Act. 2018;10(2):34-42.

12. Johnson WG, Carr-Nangle RE, Bergeron KC. Macronutrient intake, eating habits, and exercise as moderators of menstrual distress in healthy women. Psychosom Med. 1995;57(4):324-30.

13. Bertone-Johnson ER, Hankinson SE, Bendich A, Johnson SR, Willett WC, Manson JE. Calcium and vitamin D intake and risk of incident premenstrual syndrome. Arch Intern Med. 2005;165(11):1246-52. http://dx.doi. org/10.1001/archinte.165.11.1246

14. Boyle NB, Lawton C, Dye L. The effects of magnesium supplementation on subjective anxiety and stress: $A$ systematic review. Nutrients. 2017;9(5):429-51. http://dx.doi.org/10.3390/nu9050429

15. Acikgoz A, Dayi A, Binbay T. Prevalence of Premenstrual Syndrome and its relationship to depressive symptoms in first-year university students. Saudi Med J. 2017;38(11):1125-31. http://dx.doi.org/10.15537/ smj.2017.11.20526

16. Vaziri F, Hoseini A, Kamali F, Abdali K, Hadianfard M, Mehrab S. Comparing the effects of aerobic and stretching exercises on the intensity of primary dysmenorrhea in the students of universities of Bushehr. J Family Reprod Health. 2015;9(1):23-8.

17. Gençdogan B. Premenstrual sendrom için yeni bir ölçek. Turki Psikiyatri. 2006;8(2):81-7.

18. Steiner M, Streiner DL. Validation of a revised visual analog scale for premenstrual mood symptoms: Results from prospective and retrospective trials. Can J Psychiatry. 2005;50(6):327-32.

19. Mirbagher-Ajorpaz N, Adib-Hajbaghery M, Mosaebi F. The effects of acupressure on primary dysmenorrhea: A randomized controlled trial. Complement Ther Clin Practice. 2011;17:33-6.

20. Gibson RS. Part 4: Measuring food consumption of individuals. In: Principles of nutritional assessment. Oxford: University Press; 2005.

21. Sohrabi N, Kashanian M, Ghafoori SS, Malakouti SK. Evaluation of the effect of omega-3 fatty acids in the treatment of Premenstrual Syndrome: "A pilot trial". Complement Ther Med. 2013;21(3):141-6. http:// dx.doi.org/10.1016/j.ctim.2012.12.008

22. Karvonen MJ, Kentala E, Mustala O. The effects of training on heart rate: A longitudinal study. Ann Med Exp Biol Fenn. 1957;35(3):307-15.

23. Goker A, Artunc-Ulkumen B, Aktenk F, Ikiz N. Premenstrual Syndrome in Turkish medical students and their quality of life. J Obstet Gynaecol. 2015;35(3):275-8. http://dx.doi.org/10.3109/01443615.2014.948820 
24. Asci O, Kahyaoglu HS, Gokdemir F. Prevalence of Premenstrual Syndrome among university students and risk factors. DEUHFED. 2016;9(3):79-87.

25. Bakhshani NM, Mousavi MN, Khodabandeh G. Prevalence and severity of premenstrual symptoms among Iranian female university students. J Pak Med Assoc. 2009;59(4):205-8.

26. Farasati N, Siassi F, Koohdani F, Qorbani M, Abashzadeh K, Sotoudeh G. Western dietary pattern is related to premenstrual syndrome: A case-control study. Br J Nutr. 2015;114(12):2016-21.

27. Esmaeilpour M, Ghasemian S, Alizadeh M. Diets enriched with whole grains reduce Premenstrual Syndrome scores in nurses: An open-label parallel randomised controlled trial. Br J Nutr. 2019;14(9):1-25. http://dx.doi. org/10.1017/S0007114519000333

28. Ruprai RK, Kurwale M, Mankar S. The effect of regular 4 months areobic exercises on Premenstrual Syndrome on healthy females. Indian J Basic Appl Med Res. 2015;4(2):340-4.

29. Morino S, Egawa M, Hirata H, Nishimura H, Aoyama T. Association between Premenstrual Syndrome and daily physical activity levels. J Womens Health. 2016;5(5):1-4. http://dx.doi.org/10.4172/2325-9795.1000241

Received: December 12, 2018

Final version: June 24, 2019

Approved: June 28, 2019 